\title{
HENRIK MADSEN
}

\section{DER MÅ VÆRE EN KANT \\ En diskussion af forskellige opfattelser af rum og virkelighed i lyset af Kants teori om rummet}

Er ,virkeligheden“ en social konstruktion? Er det forkert at tale om en objektiv virkelighed? Er der kun forskellige opfattelser af virkeligheden? Hvordan dannes en opfattelse af virkeligheden, hvorledes konstitueres en bestemt virkelighedsopfattelse? Hvordan kan man sammenligne forskellige opfattelser af virkeligheden? Den slags spørgsmål diskuteres gerne af filosoffer og filosofiske gemytter. I de senere års filosofiske debat har emner som pluralisme, perspektivisme, relativisme og inkommensurable paradigmer stået centralt. Mange af disse temaer kan føres tilbage til Kants filosofi, og mange af de nyere positioner kan ses som modifikationer af Kants oprindelige ideer. ${ }^{1}$

Det er først og fremmest ideen om, at det vi forstår ved virkeligheden er forarbejdet af den menneskelige bevidsthed, der kan karakteriseres som neo-kantiansk. Ifølge denne opfattelse er virkeligheden en konstruktion, ikke forstået på den måde at omverdenen ikke eksisterer uafhængigt af den menneskelige bevidsthed, men sådan at virkeligheden er struktureret, eller gjort begribelig, i kraft af den menneskelige bevidsthed. Pointen er, at det vi forbinder med virkeligheden er bestemt af vores begrebsapparat. Det er muligt at der eksisterer noget ubestemt, noget udifferentieret, uafhængigt af bevidstheden, men i så fald har vi ingen ide om hvad det måtte være. „Hvad noget er“, er netop bestemt af vores begrebsapparat.

Kant hævdede at have fundet betingelserne for enhver mulig erfaring, eller den måde virkeligheden er konstitueret på af den menneskelige bevidsthed. Kants redegørelse for hvordan virkeligheden konstitueres af bevidstheden er knyttet til en opdeling af bevidstheden i forskellige anlæg eller evner. Kant skelner således mellem det han kalder „forstanden“ og ,anskuelsen“. Erfaringen af virkeligheden forudsætter begge egenskaber. Anskuelsen er bevidsthedens evne til at modtage ydre påvirkninger gennem sanserne. Forstanden er evnen til at ordne disse påvirkninger begrebsmæssigt. For Kant er betingelserne for erfaringens mulighed universelle og unikke, det vil sige at enhver bevidsthed konstituerer virkeligheden på den samme måde. Det er netop forudsætningen for forestillingen om en objektiv virkelighed og muligheden for at vi kan danne os viden om den.

Det er her mange neo-kantianske positioner tager afstand fra Kant. For det første er talen om „forstanden“ og ,,anskuelsen“ ofte droppet til fordel for et lingvistisk idiom. I stedet taler man om hvordan vi begriber virkeligheden sprogligt. Sproget er nøglen til 
den måde vi repræsenterer virkeligheden på. ${ }^{2}$ Dernæst benægtes det at der kun er én måde virkeligheden kan repræsenteres på. Tværtimod, den måde virkeligheden repræsenteres på er betinget af kulturelle og historiske faktorer. Eftersom der er mange forskellige sprog, mange forskellige kulturer, og disse har udviklet sig historisk, har vi en mangfoldighed af forskellige opfattelser af virkeligheden. Enhver opfattelse af virkeligheden er således relativ til en bestemt kultur, et bestemt sæt af sproglige kategorier, en bestemt historisk epoke. Ydermere, siden vi kun kan tale om repræsentationer af virkeligheden, og ikke om virkeligheden som den er i sig selv, har vi kun forskellige perspektiver, fortolkninger eller optikker der bestemmer vores opfattelse af virkeligheden. Der er ikke nogen objektiv virkelighed. Siden der er mange forskellige måder at opfatte virkeligheden på, bliver det problematisk hvordan vi kan sammenligne de forskellige opfattelser. For at forstå et andet verdensbillede må jeg først tilegne mig den måde at opfatte virkeligheden på, men hvordan er det muligt?

Rummet, og den måde vi opfatter rummet på, synes at være en fundamental del af vores opfattelse af virkeligheden. For Kant er rummet den måde vi anskuer alle genstande på, det vil sige at virkeligheden er konstitueret som rumlig og tidslig. Rummet som anskuelsesform er en af de nødvendige forudsætninger for mulig erfaring. Med det mente Kant, at det er umuligt at vi kan have en opfattelse af virkeligheden der ikke er rumlig. Men er det eventuelt muligt at have forskellige opfattelser af rummet? Hvis vi opgiver Kants ide om at virkeligheden nødvendigvis konstitueres på én bestemt måde, giver det måske mening at tale om forskellige måder at opfatte rummet på. Endvidere kan man bibeholde ideen om at forskellige opfattelser af rum er med til at konstituere forskellige opfattelser af virkeligheden. En sådan position er kantiansk i den forstand, at den bibeholder ideen om at rummet er konstituerende for vores virkelighedsopfattelse, men ukantiansk idet forskellige opfattelser af virkeligheden anses for mulige.

Jeg skal i det følgende argumentere for at en sådan kvasi-kantiansk position er problematisk. Først vil jeg forsøge at inddele forskellige aspekter ved rummet $\mathrm{i}$ to hovedgrupper. Dernæst forsøge at se lidt nærmere på Kants argumenter for rummet som en anskuelsesform. Jeg vil så forsøge at præcisere $\mathrm{i}$ hvilken betydning man kan tale om forskellige opfattelser af rummet. Til slut vil jeg argumentere for, at det der er holdbart $i$ Kants teori om rummet, udelukker at vi kan tale meningsfuldt om forskellige opfattelser af rummet som konstituerende for forskellige opfattelser af virkeligheden. Yderligere peger jeg på nogle begrænsninger for, hvad der kan menes med: radikalt forskellige opfattelser af virkeligheden.

\section{Objektive opfattelser af rummet}

Vi har en krop, en krop er et legeme og et legemes position kan bestemmes i forhold til andre legemers position. Med position mener vi, den del af rummet vores krop optager, og bestemmelsen af den plads kroppen optager i forhold til andre legemers position, kroppe såvel som huse, bjerge etc. Hvis man bliver ved det kropsnære, kan man hurtigt danne sig en ide om hvilke relationer der er tale om, når vi bestemmer positioner i rummet i forhold til kroppen. Man kan forestille sig en linie der skærer kroppen over ved bæltestedet. Dermed deler man kroppen i en øvre og nedre halvdel, og markerer retningerne op og ned. Hvis man yderligere trækker en linie, vinkelret på den første, der deler krop- 
pen på langs i to symmetriske halvdele, får man retningerne højre og venstre. Et tredje snit kan lægges vinkelret på de to foregående ved at dele kroppen på tværs, det giver orienteringen for og bag.

Det uhensigtsmæssige ved disse bestemmelser er selvfølgelig at de er relative til kroppens position. Til højre for mig kan være til venstre for dig. Hvis du bor på tredje, og jeg i stuen, er fruen på anden over mig, men under dig. Alligevel har vi allerede sagt noget vigtigt, man kan for eksempel hæfte sig ved, at man ikke kan trække mere end tre linier vinkelret på det samme punkt, rummet har tre dimensioner. Hvis vi opfatter de tre akser som udgørende et koordinatsystem, kan vi bestemme et hvilket som helst punkt i rummet ved at angive dets position på de tre akser. Hvis man yderligere bestemmer sig for en enhed, en favn, en fod, en tomme, kan man tilordne rummet en metrik og hæfte tal på positionerne. Det er så muligt at bestemme afstanden mellem to punkter med en talværdi.

Da hver krop har sin position, og retningsangivelser skifter alt efter kroppens position, er det praktisk at have en falles referenceramme der er invariant i forhold til kroppen. Man kan betjene sig af topografiske kendemærker, en bestemt bygning, noget der kan ses på lang afstand, kort sagt noget man kan orientere sig efter. Man kan vælge en mere global referenceramme, Syd- og Nordpol, eller en kosmisk: Stella Polaris. Den referenceramme man vælger afhænger af formålet, når man har behov for at navigere uden landkending er det rart at kunne sejle efter stjernerne, men det er upraktisk når man skal fra Amager til Køge, et kort over København og omegn er mere anvendeligt. Derfor er der noget arbitrært over disse bestemmelser, ligger New Zealand til højre eller til venstre for København? Hvorfor taler man om at grave „ned“ til kineserne? Vesten for solen, østen for månen? Rumlige positioner angives efter deres rumlige koordinater, men vores valg af koordinatsystem afhænger af pragmatiske forhold. I fysikken, hvor man forsøger at bestemme lovmæssighederne ved legemers bevægelse i rummet, bliver spørgsmålet om valget af referenceramme vigtigt. Men i det daglige orienterer vi os først og fremmest efter vores egen krops position. Vi er klar over begrænsningen $i$ at bestemme andre legemers position ud fra vores egen. Derfor bestemmer vi vores position i forhold til et mere omfattende system af relationer når vi har behov for det.

Med kroppen som udgangspunkt har vi noteret os forskellige aspekter af rummet:

1. Vi kan tale om rummet som et tredimensionalt koordinatsystem hvor bestemte positioner er punkter i dette system. På denne måde formaliseres de rumlige relationer, disse formale relationer kan aksiomatiseres som det sker i de forskellige geometriske systemer. Ved en objektiv opfattelse af rummet skal ikke nødvendigvis forstås en geometri, men blot de rumlige relationer geometrien formaliserer.

2. På den anden side orienterer vi os i rummet. Alt efter hvilke behov vi har for at bevæge os i rummet, vælger vi en referenceramme som vi bestemmer bevægelsen inden for.

Disse to aspekter: behovet for at finde vej fra punkt A til B, og den geometriske beskrivelse, forenes i kartografien.

De aspekter vi har hæftet os ved omtales ofte som objektive bestemmelser ved rummet. Dette kan forstås på to måder. For det første, som objektivt i den forstand at vi abstraherer fra alle andre træk ved legemer end deres position og rumlige relationer. Dernæst, at orientering i rummet gøres uafhængigt af den enkelte krops position. Det sker ved at inddrage en referenceramme der bestemmer den enkelte krops position i relation til mere universelle fikspunkter. 
Yderligere er der en tredje betydning af objektiv der har relation til rummet. Objektivt modstilles ofte med subjektivt, og der er en vigtig idehistorisk forbindelse mellem rummet og denne kontrast. Descartes, ofte kaldt den moderne filosofis grundlægger, skelnede mellem to substanser, res extensa og res cogitans. Han skelnede mellem bestemmelser ved materien som udstrakt, det vil sige rumlig, og bestemmelser ved bevidstheden eller subjektet. Alle materielle genstande har rumlig udstrækning og dermed position i rummet, de er en afgrænset del af rummet. Derimod har tanker og følelser ikke nogen rumlig position, de er immaterielle. Descartes' problem var at forklare hvordan subjektet kunne vide noget med sikkerhed om materien. Paradigmet på en sådan viden var i lang tid geometrien, og den geometriske beskrivelse af naturen som den kom til udtryk i det mekaniske verdensbillede.

Kants filosofi tager udgangspunkt i denne problematik, men omdefinerer forholdet mellem subjekt og objekt. Rummet er ikke en substans for Kant, og geometrien er ikke bestemmelser ved materielle genstande som de er i sig selv. I stedet er rummet og geometrien forankret i subjektet. Rummet er en anskuelsens form, og geometrien består af a priori-viden om rumlige genstande. Jeg skal senere redegøre mere udførligt for Kants position. Her vil jeg blot anføre forbindelsen mellem rummet, det ydre, og det objektive, i modsætning til det indre og subjektive.

\section{Den teoretiske og den førteoretiske opfattelse af rummet}

En ting Descartes og Kant har til fælles er, at bestemmelsen af det objektive i modsætning til det subjektive falder sammen med en teoretisk forståelse af naturen. En førteoretisk forståelse af naturen ses som uvidenskabelig, primitiv, eller vulgær. Ofte fordi den ikke skelner systematisk mellem bestemmelser ved omverdenen, der er knyttet til det enkelte individ og det samfund det lever i, og omverdenen som den forstås som teoretisk objekt for naturvidenskaben. De objektive træk ved rummet vi fremdrog udgør ikke i sig selv en teoretisk opfattelse af rummet. Men rent historisk er geometrien og fysikken intimt forbundne. Det er derfor med en vis rimelighed, at man kan kalde de bestemmelser af rummet der går ud over de objektive bestemmelser for førteoretiske. Man må blot huske på, at de såkaldte objektive træk ikke i sig selv udgør hverken en geometri eller en teori om det fysiske rum.

Der er træk ved rummet der oplagt knytter an til en førteoretisk forståelse. Man kunne måske tale om rummet som vi møder det i vores „livsverden“. ${ }^{3}$ Man kunne fristes til at tale om ,livsrummet" hvis ikke begrebet „lebensraum“" var så belastet.

Der er først og fremmest de lokaliteter og steder der har personlig betydning, fordi bestemte begivenheder eller oplevelser er knyttet til dem. Den bygning, der samtidig er mit barndomshjem, har en særlig betydning for mig. En betydning der sandsynligvis ikke deles af andre end mine søskende.

Men vi møder ikke kun rummet i form af steder der er forbundet med vores livshistorie, vi møder også rummet i form af sociale konventioner. Disse konventioner kan strække sig fra skik og brug, for eksempel som etikette i form af at holde behørig afstand; eller til lovgivning der begrænser ens fri bevægelse i form af et polititilhold. Der er således en forbindelse mellem begreber som: territorium, herredømme, jurisdiktion, og statsmagt. Denne forbindelse giver sig udtryk i begreber som: opholdstilladelse, ejendomsret, pri- 
vatsfære osv.

Endelig møder vi rummet som opdelt efter de aktiviteter der udfoldes inden for det. Vi taler om: legepladsen, arbejdspladsen, soveværelset, kirken, biblioteket osv.

Fælles for alle disse aspekter er at de normalt ikke regnes for objektive bestemmelser ved rummet. Det er en objektiv bestemmelse af en bygning at den fungerer som en kirke, men det er ikke en bestemmelse af rummet i sig selv. Dernæst er alle disse aspekter irrelevante for en naturvidenskabelig forståelse af virkeligheden. Det betyder selvfølgelig ikke at de ikke kan behandles inden for andre videnskaber, sociologi, demografi, jura, arkitektur osv. Men normalt vil den „dagligdags“ opfattelse af rummet, den måde vi oplever rummet på, falde uden for det man forstår ved en teoretisk behandling af rummet. Kants filosofi er ingen undtagelse. På spørgsmålet: hvad er rummet? ville Kant anse denne dagligdags oplevelse af rummet for at angive tilfældige træk ved den måde vi oplever genstande i rummet, ikke som træk ved rummet i sig selv.

\section{Kants opfattelse af rummet ${ }^{4}$}

Kant skelnede som nævnt mellem to forskellige komponenter i al menneskelig erfaring, anskuelsen og forstanden. Forstanden er evnen til at ordne naturen begrebsmæssigt, det vil sige samle vores forskellige forestillinger i enheder der kan skelnes fra hinanden. For Kant er denne begrebsmæssige ordning en intellektuel aktivitet der repræsenterer det formale aspekt, de såkaldte „forstandskategorier", i enhver anvendelse af begreber. I modsætning hertil kan man sætte den passive måde hvorpå sanserne registrerer forskellige indtryk og fornemmelser. Kant beskriver denne registrering af indtryk som materien uden for kroppen der påvirker materien i kroppen. Når vi opfatter sådanne indtryk, er det vi opfatter simpelthen kroppens reaktion på en påvirkning. Men det der er givet for vore sanser er ikke blot en sådan forvirring af rudimentære påvirkninger. Den materie der påvirker os, er givet for os i form af en materie der opfylder rummet og tiden, det vil sige i form af rum-tidslige genstande. Denne opfattelse af naturen som givet i rum og tid kalder Kant for anskuelsen. Erfaringen, det vil sige vores opfattelse af virkeligheden som et ordnet hele af forestillinger, muliggøres når forstanden, i kraft af kategorierne, bestemmer indholdet af anskuelsen begrebsmæssigt.

Anskuelsen bestemmer indholdet af sansningen som givet i rum og tid. Forstanden bestemmer de generelle træk der nødvendigvis må gælde for at kunne tale om genstande overhovedet. Derfor er både anskuelsesformerne rum og tid, og forstandsformerne, de forskellige kategorier, formale betingelser for mulig erfaring. De er de træk ved det menneskelige subjekt der gør, at vores forestillinger udgør et ordnet hele, ved at give form og struktur til det materiale sanserne forsyner bevidstheden med.

En af hovedhjørnestenene i Kants filosofi er hans påstand om at vi kan have en syntetisk a priori-viden om visse træk ved virkeligheden. Det vil sige viden om virkeligheden der ikke beror på erfaringen. Denne syntetiske a priori-viden er mulig fordi virkeligheden er konstitueret af forstanden og anskuelsen i fællesskab. Den syntetiske a priorividen består netop i en indsigt $\mathrm{i}$ betingelserne for enhver mulig erfaring. Hermed mener Kant, den måde forstandens kategorier anvendes på anskuelsesformerne rum og tid. Kant skelner mellem tingene som de er i sig selv (an sich) og tingene som de foreligger for os (für sich). Ifølge Kant har vi ikke nogen ide om hvad den materie der påvirker vores san- 
ser er i sig selv, vi har kun adgang til denne materie som fænomen, det vil sige som forestillinger om genstande der er givet $\mathrm{i}$ rum og tid gennem anskuelsen og ordnet gennem forstandens kategorier.

Hvad disse genstande er i sig selv, uden at være gestaltet gennem anskuelsen og forstanden, kan vi ikke gøre os nogen ide om. Jeg kan ikke forbinde noget med ideen om en virkelig genstand der ikke har en position i rummet. Eftersom vi ikke har adgang til tingene som de er i sig selv, men kun til ting som de er givet igennem den måde vi anskuer dem, siger Kant at rummet er en anskuelsesform der er knyttet til det menneskelige subjekt. Hvis der fandtes overjordiske væsner, er det således ikke sikkert, at de anskuer genstande som rumlige og tidslige fænomener.

Fordi vi kun har adgang til virkeligheden som fænomen, og ikke tingene i sig selv, har vi mulighed for at bestemme de formale aspekter af virkeligheden a priori. Vi kan for eksempel bestemme betingelserne for hvordan genstande overhovedet kan forestilles rumligt. Disse bestemmelser er indeholdt i geometrien, som derfor er en a priori-kilde til viden om virkeligheden. Anskuelsen og forstandskategorierne er konstituerende for virkeligheden, idet de bestemmer de formale træk ved enhver erfaring a priori. De bestemmer ikke erfaringens empiriske indhold men erfaringens form, eller som Kant også udtrykker det, naturen som regelmæssig eller lovbundet. For Kant gælder geometriens udsagn nødvendigvis for naturen som lovbunden.

Tanken om at der findes syntetiske a priori-domme, og at både geometriens og aritmetikkens udsagn falder under disse, er uhyre vigtig i Kants filosofiske system. For Kant er geometrien ikke blot et formalt system, eller en matematisk struktur, der er velegnet til at kodificere rumlige forhold i et konsistent system. Muligheden for at beskrive naturen videnskabeligt, det vil for Kant sige matematisk, indebærer for Kant at den euklidiske geometri gælder med nødvendighed for virkeligheden. Kant søger derfor at bevise to ting om rummet. Dels at rummet ikke er et begreb der kan dannes i erfaringen, men at det forudsættes i enhver erfaring. Dels at geometrien ikke kan opfattes analytisk, som ren begrebsmæssig analyse, men nødvendigvis forudsætter en rumlig anskuelse.

$\mathrm{Nu}$ om dage skelner vi mellem ren geometri og anvendt geometri. Vi anser det for et empirisk spørgsmål, i modsætning til noget der kan afgøres a priori, hvorvidt en bestemt formalisme stemmer overens med virkeligheden. Opdagelsen af de ikke-euklidiske geometriske systemer, og anvendelsen af disse i fysikken, er generelt blevet taget som en tilbagevisning af Kants ide om geometriens status som syntetisk a priori. Samtidig er der blevet udviklet logiske systemer der kan udtrykke de geometriske forhold Kant beskæftigede sig med rent formalt. Kants ide om rummet som en anskuelsesform er derfor også blevet opgivet.

\section{Rummets virkelighed}

Kants teori om rummet er blevet tilbagevist, har den interesse ud over som udstillingsgenstand ,i det museum vi kalder filosofiens historie“?

Med lidt god vilje, det vil sige uden at fordreje Kants tankegang alt for meget, kan vi drage nogle nyttige distinktioner inspireret af Kant. For os består virkeligheden af genstande og begivenheder der er givet i rum og tid, og man kan godt sige at vi opfatter virkeligheden rum-tidsligt. Vi har ikke den fjerneste ide om hvad virkeligheden ville være 
hvis den ikke var givet i rum og tid, så langt kan vi godt komme Kant i møde. Når vi taler om vores måde at „opfatte virkeligheden på" $i$ Kants betydning, er det vigtigt ikke at forveksle denne specielle betydning med hvad vi normalt mener, når vi taler om en persons „virkelighedsopfattelse“. Hvis man siger om en person, at der er noget galt med hendes virkelighedsopfattelse, så mener man at denne person har forkerte eller misvisende forestillinger om virkeligheden. Kant ville sige at en sådan person dømmer forkert, eller siger noget der er forkert, man hævder at tingene forholder sig på en måde som de rent faktisk ikke gør. Men en betingelse for overhovedet at kunne hævde noget om virkeligheden, hvad enten det er rigtigt eller forkert, er netop at der er en virkelighed man kan hævde noget om. Hvis man sagde om en person, at hendes virkelighedsopfattelse var anderledes, fordi hun ikke opfattede genstande som givet i rum og tid, ville det være misvisende at sige at hun har en forkert opfattelse af virkeligheden. Vi ville ikke kunne forbinde noget med en sådan opfattelse. Det er svært gennemskueligt hvordan vi overhovedet kunne kommunikere med hende. Hvordan kan man kommunikere med en person der ikke behersker udtryk som: „her“, „der“, ,nu“, og som ikke kan definere udtryk ostentativt ved at pege ud i rummet, og som derfor ikke kan identificere og genkende genstande? Selve begrebet om en genstand indebærer noget rumligt.

\section{To betydninger af „virkelighedsopfattelse“}

For Kant er virkeligheden som sagt konstitueret af det erkendende subjekt, det er Kants transcendentale idealisme; men det er kun formale træk ved virkeligheden der konstitueres af subjektet: betingelserne for erfaring overhovedet. Det er ikke indholdet af erfaringen der konstitueres på denne måde. I det følgende vil jeg omtale de betingelser for at vi overhovedet forstår noget ved udtrykket „virkelighed“ som: opfattelsen af virkeligheden i ,snæver“ betydning. De træk ved rummet jeg har omtalt der gik ud over de objektive bestemmelser ved rummet, de usystematiske, idiosynkratiske træk ved oplevelsen af rum, de konventionelle aspekter, eller videnskabelige teorier, har alle med indholdet af vores erkendelse at gøre. I modsætning til den „,snævre“ opfattelse af virkeligheden vil jeg kalde en opfattelse af virkeligheden der har med indholdet af virkeligheden at gøre for „bred“.

Kant understregede at indholdet af erfaringen ikke må forveksles med betingelserne for mulig erfaring. I min terminologi vil det sige at man ikke må forveksle den snævre og den brede betydning af ,virkelighedsopfattelse“. Uden at falde tilbage i Kants terminologi om anskuelsesformer og forstandskategorier kan man fastholde en del af hans tankegang. Man kan således forsøge at skelne mellem betingelser for, at vi overhovedet kan forbinde noget sammenhængende med virkeligheden, og forskellige opfattelser af hvordan denne virkelighed er beskaffen. At materielle genstande har en rum-tidslig position er således en nødvendig betingelse for at jeg kan beskrive virkeligheden. At den samme genstand ikke kan være to steder på en gang er ligeledes en del af min virkelighedsopfattelse i den snævre betydning. Hvis jeg forsøger at benægte sådanne påstande kommer jeg $\mathrm{i}$ vildrede. Ikke fordi jeg er $\mathrm{i}$ tvivl om denne eller hin beskrivelse af forhold i virkeligheden er korrekt; men fordi jeg ikke ved hvad jeg skal forbinde ved udtrykket ,virkelighed" når jeg forsøger at benægte dem. En del af de rumlige bestemmelser vi karakteriserede som objektive træk ved rummet har netop denne karakter.

Det betyder, at når vi taler om at have en anden opfattelse af rummet kan vi ikke tage 
sigte på disse objektive bestemmelser ved rummet. Men så følger det, at det vi mener med en forskellig opfattelse af rummet må være rummet som en del af en virkelighedsopfattelse i den brede betydning. Heraf følger det, at en divergerende opfattelse af rummet ikke kan ligge til grund for forskellige virkelighedsopfattelser. Vi har slået fast at vi ikke kan forestille os alternativer til de objektive træk, for det indebærer at vores begreb om virkeligheden smuldrer, ikke en bestemt opfattelse af virkeligheden, men enhver virkelighedsopfattelse. Det andet alternativ er, at andre af de aspekter ved rummet vi har hæftet os ved kan konstituere forskellige virkelighedsopfattelser. I det følgende skal jeg argumentere for at sådanne opfattelser af rummet ikke kan siges at „,konstituere“ noget som helst. De betegner blot forskellige måder at karakterisere dele af vores omverden på. Det er kun de objektive træk ved rummet der kan siges at være konstituerende for vores opfattelse af virkeligheden. De andre træk ved rummet er en del af en virkelighedsopfattelse i bred forstand, det vil sige meninger om hvordan tingene forholder sig i virkeligheden og min mening om denne tingenes tilstand.

Som sagt kan jeg ikke forbinde noget med udtrykket ,virkelighed“ med mindre visse minimumskrav er opfyldt. Man kan derimod godt forestille sig at der er divergerende opfattelser af hvordan virkeligheden er beskaffen, hvordan tingene forholder sig i virkeligheden. Jeg forstår godt hvad meningen er hvis personer påstår at de er Napoleon Bonaparte, eller at de var Napoleon i et foregående liv, eller for den sags skyld at de samtaler med Napoleons ånd. Men jeg er overbevist om at de tager fejl, de har en forkert opfattelse af virkeligheden i den brede betydning: ,forhold i virkeligheden“. Det betyder ikke at jeg ikke kan respektere mennesker der er spiritualister, men det betyder at jeg ikke kan acceptere det de er overbevist om, at der eksisterer ånder.

I den forstand er der ikke nogen forskel på den teoretiske, og den førteoretiske opfattelse af rummet. Hvis en videnskabelig teori hævder at rummet har en krumning kan jeg være enig eller uenig. Alt efter mit kendskab til fysik kan min mening være mere eller mindre velbegrundet. Pointen er at en sådan teori siger noget om hvordan det forholder sig i virkeligheden, og som sådan er den en del af en videnskabelig opfattelse af virkeligheden. Men man behøver ikke at være fysiker for at have en objektiv opfattelse af virkeligheden, det vil sige virkeligheden i den snævre forstand. Jeg kan benægte den fysiske teori uden at min virkelighedsopfattelse i snæver forstand lider overlast.

Som før nævnt er der en filosofisk tradition der har identificeret udtrykket ,objektiv virkelighed" med en teoretisk, specielt naturvidenskabelig, forståelse af omverdenen. Der har været en tendens til at identificere træk ved den snævre, eller formale, virkelighedsopfattelse med den bredere, i betydningen: virkelighedens beskaffenhed. Det var netop en del af Kants projekt for geometriens vedkommende. Men som vi så var det den del af hans system der brød sammen. Netop ved ikke at skelne mellem anvendt og ren geometri forveksledes betingelser for erfaringens mulighed med indholdet af en mulig erfaring.

Hvis vi siger, at nogen har en anden opfattelse af rummet, må vi derfor sigte til det vi forstod ved opfattelsen af rummet i den dagligdags betydning, eventuelt en teoretisk/videnskabelig betydning. Inddrager vi en personlig opfattelse af rummet, er det oplagt at rummet kan opfattes forskelligt, vi har alle vores minder, forhåbninger, og så videre, der knytter sig til bestemte lokaliteter. Det er også oplagt at sammenkædning af rum med bestemte gøremål, sociale konventioner og så videre kan opfattes forskelligt alt efter hvilken kultur eller samfund man lever i. Er sådanne forskellige opfattelser af rum konstituerende for en anden opfattelse af virkeligheden? Ikke i Kants forstand, så meget skulle 
være klart. Disse opfattelser af rum er psykologisk, kulturelt, og socialt betinget. De er alle empiriske i den forstand at de har at gøre med en karakteristik af konkrete forhold i virkeligheden. Men de forudsætter alle at vi kan tale om, og referere til, genstande i rummet. Hvis jeg får at vide, at et bestemt rum i en bygning er tabu for alle af hankøn over tolv år når månen er fuld, er det tvivlsomt om jeg oplever dette rum på samme måde som dem der er opvokset i den kultur hvor denne konvention er udbredt. Men det er også tvivlsomt, om andre oplever det gadehjørne hvor jeg fik mit første kys på samme måde som jeg gør. Problemet er, at hvis man hævder, at den måde jeg oplever et bestemt rum på gør at jeg har en anden opfattelse af virkeligheden, fordi min opfattelse af virkeligheden er konstitueret af sådanne oplevelser, så kan man med lige så god ret hævde at vi alle har forskellige opfattelser af virkeligheden. Enten er en sådan opfattelse absurd fordi den i yderste konsekvens ender i solipsisme, eller også reduceres udtrykket ,opfattelse af virkeligheden" til noget trivielt. Det faktum at jeg kan referere til det tabubehæftede rum som: ,det forbudte rum“, og jeg ved hvor det befinder sig i bygningen, er ganske banalt; men denne evne forudsætter ikke desto mindre at jeg kan orientere mig i rummet, og at jeg formår at fastlægge dets rumlige position. Dette forudsætter igen at jeg opfatter virkeligheden som bestående af genstande med rumlige relationer til hinanden. Det er denne minimale forståelse af rumlighed der kan siges at være konstituerende for virkeligheden i Kants forstand. Ikke den måde jeg opfatter dette eller hint rum på.

\section{Forskellige opfattelser af virkeligheden?}

Vi kan skelne mellem tre forskellige betydninger af hvad der menes med ,forskellige opfattelse af virkeligheden“. I den første betydning drejer det sig om udsagn man anser for fejlagtige. Hvis jeg får at vide, at overskridelsen af et tabu vil medføre at jeg bliver genfødt som en hund, vil min nattesøvn ikke blive forstyrret. Jeg accepterer ikke teorien om reinkarnation som gyldig. I den anden betydning drejer det sig om hvordan vi oplever virkeligheden forskelligt, og dermed opfatter den forskelligt. Men denne betydning er enten absurd eller komplet uskyldig. Begge disse betydninger hører under det jeg har kaldt den „brede“ betydning. Den tredje mulighed, det jeg har kaldt virkeligheden i snæver betydning, er den der ligger nærmest den kantianske. Men her drejer det sig om nogle rudimentære færdigheder såsom evnen til at orientere sig i rummet, og hvad der må forudsættes om virkeligheden for at det giver mening at tale om rumlig orientering overhovedet.

Man kan gerne bestemme disse minimale bestemmelser ved virkeligheden som formale. På linie med Kant kan man også gerne sige at de er konstituerende for vores opfattelse af virkeligheden, men dermed mener man blot at vi har svært ved at forbinde noget med „virkeligheden“ hvis disse betingelser ikke er gældende. Det ville være umuligt at kommunikere med nogen der ikke opfattede virkeligheden på samme måde i denne minimale forstand.

Det problematiske ved de teorier jeg har kaldt kvasi-kantianske er, at de ofte blander de forskellige betydninger af ,virkelighedsopfattelse“ sammen. Disse teorier, hvad enten de taler om „conceptual schemes“, „systems of categories“, „cognitive frames“, eller „systems of cognitive metaphors“ har det til fælles med Kant at de anser vores opfattelse af virkeligheden som betinget, eller determineret, af et bestemt begrebsapparat. Det holdbare i Kants position er ideen om at der er visse minimumsbetingelser der må være 
opfyldt for at vi kan forbinde noget med en beskrivelse eller forestilling om virkeligheden. Det er sikkert urealistisk at tro, som Kant gjorde, at der er et nøje afgrænset sæt af betingelser for mulig erfaring. Men vi behøver ikke forudsætte at der er en komplet liste over sådanne betingelser. Som vi har set tyder meget dog på at visse rumlige relationer, der forudsættes når vi orienterer os rumligt, burde være på listen. Men disse betingelser muliggør erfaring, de bestemmer intet om erfaringens indhold. Det er derimod kendetegnende for de kvasi-kantianske teorier at de betragter virkelighedens beskaffenhed, eller indholdet af erfaringen, som bestemt af begrebsapparatet. ${ }^{5}$

En uheldig konsekvens ved de kvasi-kantianske opfattelser er at vi gøres til epistemiske slaver af et bestemt begrebsapparat. Det er utvivlsomt rigtigt at objekter og begivenheder kan klassificeres forskelligt, og med forskellige formål for øje. Endvidere er det oplagt at sådanne klassifikationer kan være kulturelt betinget. Men når man hævder, at sådanne klassifikationer er konstituerende for opfattelsen af virkeligheden, og virkeligheden derfor kan konstitueres på radikalt forskellige måder, forveksler man betingelser for mulig erfaring overhovedet med en specifik måde at opfatte virkeligheden på. En specifik måde at opfatte virkeligheden på må enten opfattes som meninger om hvordan virkeligheden er beskaffen, eller som en bestemt måde at opleve forskellige situationer eller begivenheder på. Men når man siger at sådanne specifikke måder at opfatte virkeligheden på er bestemt af et bestemt begrebsapparat, så indebærer det at jeg er tvunget til at opfatte virkeligheden på den og den måde. Men jeg er ikke tvunget til at tro på den generelle relativitetsteori, julemanden, eller noget som helst andet om virkelighedens beskaffenhed. Det er rigtigt at visse aspekter af den måde jeg oplever virkeligheden på er betinget af min opvækst, uddannelse etcetera, og det er rigtigt at hvad jeg tror, håber og føler ofte blandes sammen. Når man bruger vendingen: ,jeg oplever det som om...“, er det ikke altid klart om personen udtaler sig om hvordan tingene rent faktisk forholder sig, hvordan de burde forholde sig, eller blot delagtiggør andre i sine følelser. Men det forandrer intet ved at disse måder at „opleve virkeligheden på“ sagtens kan gøres til genstand for diskussion. Det er unægteligt rigtigt at de involverer anvendelsen af vores begrebsapparat og dets sproglige iklædning, men det indebærer ikke at de er konstituerende for virkeligheden og derfor uomgængelige eller indiskutable.

Hvis jeg ikke mener at det begrebsapparat jeg selv er udstyret med tvinger mig til at acceptere bestemte forhold i virkeligheden, hvorfor skulle jeg så formode at det er tilfældet for fremmede folkeslag? Hvorfor skulle jeg antage at deres virkelighedsopfattelse er dem påtvunget af deres kultur på en måde jeg ikke selv anerkender. Man kan selvfølgelig hævde at jeg er et ubevidst offer for mit begrebsapparat. Jeg er ikke selv klar over i hvilket omfang min opfattelse af virkeligheden er påvirket og bestemt af sprog, kultur, etc. Hertil vil jeg så svare, at hvis den eneste måde man kan undgå at være kognitivt samspilsramt på er ved at anskue ens eget begrebsapparat udefra - in toto, ja så er det selvfølgelig umuligt. Men dette er et urimeligt forlangende. Det er nok at jeg kan tage stilling til, og vurdere, mange forskellige forhold i virkeligheden. Jeg behøver ikke at kunne gennemskue alt på en gang. Jeg benægter ikke at jeg tager visse ting for givet, at der findes blinde punkter og så videre, pointen er at det er principielt muligt at diskutere dem, og eventuelt revidere dem. Det er netop en af farerne ved de kvasi-kantianske opfattelser, man forledes til at tro at man ikke kan tage stilling til et enkelt sagforhold uden samtidig at tage stilling til et helt verdensbillede.

Kants ide om subjektets konstitution af virkeligheden gik på formale kriterier, hvis 
disse betingelser ikke er opfyldt bryder vores forståelse af virkeligheden sammen. Vi kan som nævnt ikke forbinde noget med begrebet om en ting der ikke har rumlig position, der ikke udfylder et bestemt rum. Hvis man derimod taler om en konstitution af virkeligheden hvor det drejer sig om indholdet af virkeligheden, hvad det er vi oplever, så forveksler man formelle krav om meningsfuld tale overhovedet med bestemte konkrete betydninger eller fortolkninger. De formale betingelser der gør sammenhængende tænkning mulig er en forudsætning for at en bestemt fortolkning kan komme i stand, men de fastlægger ikke en bestemt fortolkning. Hvis man forveksler de to ender man i en position hvor man enten hævder at hver enkelt person konstituerer sin egen virkelighed, eller i en opfattelse hvor man påtvinges bestemte meninger og holdninger af ens begrebsapparat.

Når jeg mødes med en fremmed kultur eller sprog, forudsætter jeg min egen opfattelse af virkeligheden. Ud fra den forsøger jeg at forstå det fremmede; men hvis ikke jeg allerede forudsatte visse betingelser opfyldt, som for eksempel at ting har position i rum og tid og rummet har tre dimensioner, både i min og den fremmedes opfattelse af virkeligheden, så er det uklart om vi overhovedet kan kommunikere.

Hvis der er store kulturelle forskelle kan det være svært at forstå hinanden, men det er ikke fordi vi konstituerer virkeligheden på forskellig vis og derfor opfatter den forskelligt. Man kunne med lige så god ret hævde at en uldjyde og en københavner konstituerer virkeligheden forskelligt. Uldjyden oplever storbyen som skræmmende, københavneren oplever heden som kedelig, den ene stemmer på Venstre den anden er socialdemokrat, de er rygende uenige om dette og hint. Det faktum at det er svært for dem at enes om noget betyder ikke at deres virkelighed er konstitueret forskelligt, hvis det var tilfældet ville de ikke have noget at være uenige om.

Hvad betyder det for begrebet om rummet? Det betyder at man bør skelne mellem de forskellige måder vi møder rummet på, deler det op på, taler om det på, alle de forskellige måder rummet har betydning for os; og den måde rummet forudsættes som en betingelse for overhovedet at kunne forstå noget ved begrebet virkelighed. Den første betydning af rum er på mange måder langt den mest interessante, fordi den fortæller en masse om hvem vi er og hvordan vi opfatter virkeligheden i den brede betydning. Den anden, den „kantianske“, er mindre oplysende, men en forudsætning for at vi overhovedet kan have en opfattelse af virkeligheden, og dermed, af og til, have forskellige meninger om hvordan den er beskaffen. Det vi må forudsætte som fælles udgør det absolutte minimum for overhovedet at kunne tale sammen, for uden det ville vi ikke have noget at tale om. Der ville ikke gives forskellige perspektiver for alt ville være perspektivtløst.

Andre kulturer kan gerne have forskellige opfattelser af rummet, og opfattelser om virkelighedens beskaffenhed der divergerer fra vores egen; men selve mødet med andre kulturer forudsætter dog at vi befinder os i det samme fysiske rum. 


\section{Noter}

1. Der er en omfattende litteratur om disse emner, men jeg kan anbefale to antologier: M. Krausz (ed.): Relativism. Interpretation and Confrontation (1989) og M. Hollis \& S. Lukes (eds.): Rationality and Relativism (1982).

2. Som et eksempel på en sådan opfattelse kunne man nævne Mark Johnsons og George Lakoffs teori om hvordan et system af kognitive metaforer strukturerer vores opfattelse af virkeligheden (Johnson \& Lakoff 1980).

3. Udtrykket „livsverden“ har forskellige betydninger i den filosofiske tradition. Udtrykket stammer oprindelig fra Husserl. I sit skrift Die Krisis der europäischen Wissenschaften und die Phänomenologie undersøger Husserl forholdet mellem en førteoretisk og en naturvidenskabelig opfattelse af virkeligheden. Det er en af Husserls pointer at „livsverdenen“ er en transcendental betingelse for erfaring. Det er en af mine pointer i denne artikel at hvis man med „livsverden“, i forbindelse med rummet, ikke forstår andet end rumlige oplevelser hvor rummet i sig selv ikke tematiseres, så bør sådanne oplevelser ikke anses som nødvendige betingelser for mulig erkendelse.

4. Dette er en meget ufuldstændig og nødtørftig gennemgang af Kants teori om rummet. Kant beskæftigede sig indgående med rummet igennem hele sit forfatterskab. Rummet og dets forbindelse med geometrien er af så central betydning i Kants teoretiske filosofi, at det er vanskeligt at sige bare lidt om det uden at komme ind på andre dele af Kants filosofi. Jeg håber blot at kunne sige nok til, at det bliver forståeligt hvordan jeg opfatter Kants position i forhold til de aspekter af rummet jeg har kaldt henholdsvis ,objektive“ og „dagligdags“. Det sted i Kants værk man oftest ser refereret til i forbindelse med hans opfattelse af rummet er: Kritik der Reinen Vernunft, Transzendentale Elementarlehre, Erster Teil § 1-8. (Kant 1956). For en grundig gennemgang af forbindelsen mellem rum, geometri og naturvidenskab i Kants forfatterskab kan jeg anbefale: Friedman, M.: Kant and the Exact Sciences (1992).

5. For en lignende opfattelse se James Bohman 1991:129-54.

\section{Litteratur}

Bohman, James

1991 Holism without Scepticism: Contextualism and the Limits of Interpretation.

I: Hiley, David R., James F. Bohman \& Richard Shusterman (eds.): The Interpretive Turn.

Ithaca, N.Y.: Cornell University Press.

Friedman, Michael

1992 Kant and the Exact Sciences. Cambridge, Mass.: Harvard University Press.

Hollis, M. \& S. Lukes (eds.)

1982 Rationality and Relativism. Cambridge, Mass.: MIT Press.

Husserl, Edmund

1966 Die Krisis der europäischen Wissenschaften und die transzendentale Phänomenologie.

Ergänzungsband: Texte aus dem Nachlass, 1934-1937. Hrsg: Reinhold N. Smid. Husserliana: gesammelte Werke von Edmund Husserl 29. The Hague: Husserl-Archiv/Dordrecht: Kluwer.

Johnson, Mark \& George Lakoff

1980 Metaphors We Live By. Chicago, Ill.: University of Chicago Press.

Kant, Immanuel

1956(1781a, 1787b) Kritik der Reinen Vernunft. Hamburg: Felix Meiner Verlag.

Krausz, Michael (ed.)

1989 Relativism. Interpretation and Confrontation. Notre Dame, Ind.: Notre Dame University Press. 